
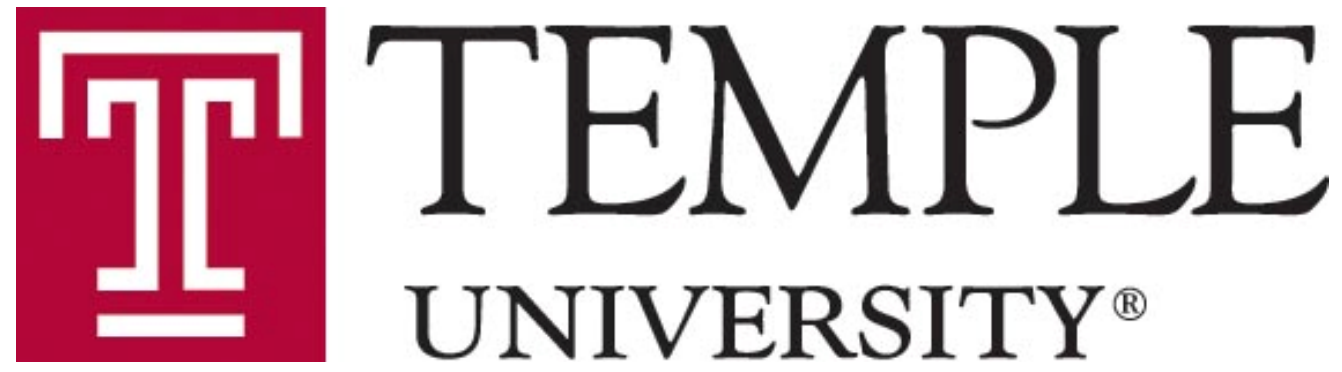

\title{
Monetary Policy and Credit Cards: Evidence from a Small-Open Economy
}

by

Hakan Yilmazkuday

Department of Economics

DETU Working Paper 10-10

September 2010

1301 Cecil B. Moore Avenue, Philadelphia, PA 19122 http://www.temple.edu/cla/economics/ 


\title{
Monetary Policy and Credit Cards: Evidence from a Small-Open Economy ${ }^{1}$
}

\author{
Hakan Yilmazkuday ${ }^{2}$ \\ Temple University
}

\begin{abstract}
This paper uses a unique monthly data set that covers overall credit card usage in a small-open economy, Turkey, to investigate a possible credit channel of monetary policy transmission through credit cards. A reduced-form vector autoregression analysis is employed where the forecast error variance decompositions are calculated for three-year windows over the period 2002-2009. It is shown that, during the recent financial crisis that has started in 2007, the monetary policy of Turkey has shifted toward focusing on output volatility and interest-rate smoothing through setting short-term interest rates, while the inflation rate has been mostly affected by exchange rate movements and inflation inertia. Credit cards usage has an increasing effect on inflation rates through time, requiring more policy emphasis on the credit channel through credit cards. When the effects of the credit view and the money view are compared, the former seems to be more effective on the real side of the economy independent of the level of inflation.
\end{abstract}

JEL Classification: E44, E50, E60, C32

Key Words: Credit Cards, Monetary Policy, Credit Channel, Vector Autoregression, Turkey.

\section{Introduction}

There is a well-known debate between the money view and credit view of monetary policy. The former, by assuming all non-money assets are perfect substitutes, emphasizes the money supply affecting aggregate demand through short-term interest rates. The latter goes one step further and states, by assuming that bank loans are imperfect substitutes to other non-money assets, that the money supply affects aggregate demand not only through short-term interest rates but also through new bank loans. ${ }^{3}$ Within this context, the contemporary payment methods, such as credit cards, come into the picture emphasizing more the role of credit view - so called the credit channel of monetary policy transmission. ${ }^{4}$

\footnotetext{
${ }^{1}$ The author thanks Stephen Hall and two anonymous referees for their helpful comments and suggestions. The usual disclaimer applies.

${ }^{2}$ Department of Economics, Temple University, Philadelphia, PA 19122, USA; Tel: +1-215-204-8880; Fax: +1-215-204-8173; e-mail: hakan.yilmazkuday@temple.edu

${ }^{3}$ Although most of the empirical evidence supports the credit view (see Bernanke, 1993, and the discussion therein), the exceptions that empirically find money view more significant than credit view are King (1986), Romer and Romer (1990), and Ramey (1993).

${ }^{4}$ See Brady (forthcoming) for an excellent literature survey on consumer credit and the transmission mechanism of monetary policy.
} 
In particular, in the credit channel of monetary policy transmission, contractionary monetary policy can force constrained financial institutions (constrained on both sides of their balance sheet) to restrict lending through credit cards independent of the demand for loans. ${ }^{5}$ For borrowers dependent on financial institutions through credit cards, contractionary monetary policy restricts their source of credit and increases the costs of seeking alternative sources. ${ }^{6}$ Therefore, the most compelling literature on lending effects focuses on the relationship between small banks and small borrowers. Kashyap and Stein (1995, 2000), and Gertler and Gilchrist (1993, 1994) provide a combination of empirical evidence showing that small commercial banks do contract lending after a negative policy shock, and small firms are affected by that contraction. ${ }^{7}$ The "small” commercial bank assumption is important, since it is assumed that the small borrower relies on a special relationship with the small bank for its credit, and finds it difficult to get credit from larger banks, or from non-bank alternatives; this is the exact case in the market for credit cards.

Within the big picture of credit markets, this paper investigates possible interactions between credit card usage and the monetary policy in a small-open economy, Turkey, which has experienced an increasing credit card usage, especially after 2002. In particular, the volume of transaction with credit cards (i.e., credit card usage) has increased from 24 billion Turkish Liras (16 billion Euros) in 2002 to 200 billion Turkish Liras (92 billion Euros) in 2009. During the same period, the real volume of credit-card transactions (defined as credit card usage in Turkish Liras over the Turkish consumer price index) has increased by 465 percent, while the number of transactions has increased from 630 million to 1.83 billion; these correspond to an increase in the GDP share of credit card usage from $6 \%$ to $20 \%$. On the consumer side, the number of credit cards in Turkey has increased from 14 million to 45 million during 2002-2009; this corresponds to a credit-card-per-capita measure of 0.6 in 2010. On the firm side, the number of POS machines has increased from 0.3 million to 1.7 million during 20022009. More importantly, the share of credit card usage within the overall consumer credit market is, on average, around 20\% during 2002-2009. From a policy maker’s point of view, these improvements require an increasing focus on the credit channel of monetary policy transmission through credit cards. ${ }^{8}$

Although underlying factors that influence individual credit card usage may mostly be at the micro level as discussed above, the aggregate credit card usage can be affected by the following macroeconomic variables: (i) prices as one of the most significant factors through the quantity theory of money; (ii) interest rates representing the opportunity cost of credit card usage, especially when credit-card debt is not paid on time; (iii) exchange

\footnotetext{
${ }^{5}$ See Bernanke and Gertler (1995) for a detailed survey of the lending channel.

${ }^{6}$ See Kashyap and Stein (1995), and Gertler and Gilchrist $(1993,1994)$ for detailed discussions on the link between commercial banks and contractionary monetary policy.

${ }^{7}$ See also Kishan and Opiela (2000).

${ }^{8}$ For details about the history of payment cards in Turkey, see Yazgan and Yilmazkuday (2009).
} 
rates as one of the main determinants of prices through international trade; (iv) production level as a measure for overall health of the economy. For sure, these are interacting factors/variables (e.g., credit card usage may affect prices through high demand of individuals financed by credit cards; or monetary authority may use shortterm interest rates for the sake of price stability which may further credit card usage through both interest rates and prices with opposite signs; or credit card usage may lead to more expensive expenditures such as internationally traded products which in turn will affect exchange rates, prices, interest rates, and output, etc.); hence, a reduced-from vector autoregression (VAR) framework is employed to analyze the credit channel of monetary transmission mechanism through credit card usage. Considering the sample period of 2002-2009, VAR framework will not only allow obtaining impulse response functions and variance decomposition analysis for included macroeconomic variables but also will lead to a complete analysis of the Turkish economy during its inflation targeting experience in both nominal and real terms through monetary and credit points of view. ${ }^{9}$

The results show that, although credit card usage has been affected only around 3-4\% by the monetary policy shocks (through short-term interest rates), it has been relatively affected more during the implicit inflationtargeting regime (which corresponds to a high level of inflation) compared to the explicit inflation-targeting regime (which corresponds to a low level of inflation), suggesting that low-inflationary regimes are more suitable for a healthier (less volatile) credit card market. Due to relatively higher volatilities in exchange rates during the explicit inflation-targeting period, credit card usage has been affected by exchange rate movements by almost double (around 8\%) during that period compared to the implicit inflation-targeting period (around $4 \%$ ). When it comes to real shocks, credit card usage has been affected by $14 \%$ on average during the sample period; when we consider implicit and explicit inflation targeting periods separately, the former corresponds to an output effect on credit card usage of $18 \%$ while the latter corresponds to an effect of $17 \%$. Finally, as expected, the movements in inflation have been more influential on credit card usage during the implicit inflation-targeting period which corresponds to a higher level of inflation.

More important policy implications are on the real side of the economy: during the implicit (respectively, explicit) inflation-targeting period, the movements in output are determined at around 11\% (respectively, 5\%) through credit card usage, around 8\% (respectively, 3\%) by the short-term interest rates, another 8\% (respectively, $0.5 \%$ ) by inflation, and 13\% (respectively, 1\%) by exchange rates. This suggests that output has become self-explanatory during the explicit inflation-targeting regime, which is an indicator of a more stable real economy. This result also has an important policy implication: both the credit view (through credit cards) and the monetary view (through short-term interest rates) seem to be more important during high inflationary

\footnotetext{
${ }^{9}$ The following studies have also employed VAR frameworks for the Turkish economy: Berument and Pasaogullari (2003); Leigh and Rossi (2002); Diboglu and Kibritcioglu (2004); Berument (2007); Us (2004); Civcir and Akcaglayan (2010).
} 
episodes for the real side of the economy. When one compares the credit view with the money view, the former seems to be more effective on the real economy during both implicit and explicit inflation-targeting periods (i.e., this last result is independent of the level of inflation). From a policy maker's point of view, this result justifies the motivation of the paper, as depicted above, that there is an increasing necessity for considering the credit channel of monetary policy transmission through credit cards.

\section{Data and Methodology}

The monthly variables included in the analysis are industrial production index (as a measure of output), real credit card usage (defined as the total credit card usage divided by the consumer price index), short-term interest rates (overnight interbank interest rates as a measure of monetary policy), inflation rate (defined as the first log difference in consumer price index), and exchange rates (defined as the price of Euro in Turkish Liras). The specification is standard in that it includes a variable capturing real activity, a variable of credit markets, a variable representing monetary policy, a price index, and a variable representing international transactions. All variables are annual percentage changes that have been seasonally adjusted and Hodrick-Prescott (HP) filtered, where the latter is mostly because the original variables are not stationary due to decreasing inflation rates during the inflation targeting regime that has started in January 2002. The monthly data covering the period over 2002-2009 have been obtained from the web page of Global Insight except for credit card usage data that have been obtained from Interbank Card Center of Turkey. Further details of the data are depicted in Data Appendix. $^{10}$

A reduced-from VAR framework is employed to analyze the credit channel of monetary transmission mechanism through credit card usage. First, using several individual and group unit root tests, it is confirmed that all included variables (as described above) are stationary; this is expected considering the HP filtered data. Second, Granger causality tests used to determine the causality between bilateral variables suggest an ordering of variables within the VAR as they have been introduced above. ${ }^{11}$ Finally, the lag length is determined as two

\footnotetext{
${ }^{10}$ Some studies have used other possible variables in VAR analyses on Turkish economy with forecast error variance decompositions to explain the movements in prices and output: (i) Berument (2007) has employed spread between interest and exchange rates, together with money, price, and output measures, in a VAR analysis on Turkey; both spread and money have been found to be not explanatory for prices or output; (ii) Berument and Pasaogullari (2003) have found that real exchange rates are not explanatory for output; (iii) Leigh and Rossi (2002) have found that oil prices account for only around 6 percent of prices, although they do not talk about the significance of their results; (iv) Diboglu and Kibritcioglu (2004) show that output is mostly affected by terms of trade and supply shocks.

${ }^{11}$ In particular, according to the Granger causality test results with 2 lags, exchange rate causes interest rate and inflation at $5 \%$ significance level, inflation causes interest rate at the $1 \%$ and credit card usage at the $10 \%$ significance levels, interest causes credit card usage and output at the $10 \%$ significance level, credit causes output at the $10 \%$ significance level, and output does not cause anything.
} 
according to several criteria. ${ }^{12}$ Since these are all standard tests, their details have been skipped to save space but are available upon request. ${ }^{13}$

In addition to the standard VAR analysis, the novelty of this paper comes into the picture through investigating possible nonlinearities by two robustness tests:

1. The sample period is divided into two, 2002:M1-2005:M12 and 2006:M1-2009:M12, to consider possible nonlinearities in the VAR analysis, where the first period represents the implicit inflation targeting regime, and the second period represents the explicit inflation targeting regime. ${ }^{14}$ Another reason for the selection of such a break date is the change of the governor of the Central Bank of Turkey at the beginning of 2006. The impulse response functions and forecast error variance decompositions will depicted be for each period in the next section.

2. A moving-window VAR analysis is used to consider nonlinearities in the VAR framework where the window length has been set to three years (i.e., 36 months). The selection of three-year window lengths is mostly to keep the window size minimal to have a more detailed nonlinear analysis; longer windows would only have a smoothing effect on the results. ${ }^{15}$ The forecast error variance decompositions will be depicted for each three-year window in the following section.

\section{Empirical Results}

The results are depicted as impulse response functions and forecast error variance decompositions.

\subsection{Impulse Response Functions}

The impulse response functions for the period over 2002-2009 are depicted in Fig. 1. As is evident, the shortterm interest rates are significantly and positively affected only through shocks of inflation, exchange rates, and lagged interest rates, while there are no significant effects of output and credit card usage. This shows evidence of a Taylor-rule type monetary policy with interest-rate smoothing followed by the Central Bank of Turkey where the main goal is price stability (rather than output volatility) as depicted on their web page. ${ }^{16}$ The statistical significance of the effects of these shocks on the short-term interest rates is up to three months

\footnotetext{
${ }^{12}$ In particular, final prediction error and Akaike information criterion has exactly selected two lags, sequential modified LR test has selected 5 lags, and Schwarz and Hannan-Quinn information criteria have selected 1 lag; within this picture, we have employed two lags in the analysis. Moreover, short-run restrictions are assumed in order to identify the structural VAR; this is achieved by recursive identification through a Cholesky decomposition with the variables ordered as listed above. In making this assumption, it has been followed what has been a standard identification practice with VARs in the credit channel literature; see Brady (forthcoming) for further discussion on this topic.

${ }^{13}$ The model of this paper has also been compared with a restricted model where credit card usage has been excluded; both Akaike information and Schwarz criteria have selected the model of this paper.

${ }^{14}$ See Kara (2006) for an analysis of implicit inflation targeting experience in Turkey.

${ }^{15}$ Such smoothing effects, which do not alter the main results of this paper at all, can be observed through modifying Matlab codes of the author which are available upon request.

${ }^{16}$ For sure, this is a merely observational claim that is necessary for the existence of or an approximation by a Taylor rule; formal statistical tests are needed to establish the sufficiency of this claim, which is out of the scope of this paper.
} 
providing more insight of the central bank behavior. During the same period, the inflation rate seems to be significantly affected only through shocks of exchange rates and lagged inflation rates, depicting the role of international shocks and inflation inertia in a small open economy that has experienced high inflationary episodes for more than two decades. Similarly, output has been significantly affected mostly through shocks of exchange rates and lagged output showing possible roles of international trade volatility on the real side of the economy. Credit card usage has been positively and significantly affected mostly through shocks of output and lagged credit card usage only up to two periods, suggesting that the effects of real activity (or income) on available credits is minimal; this highlights the role of credit cards as a consumption-smoothing tool. Finally, exchange rates seem to be positively and significantly affected mostly through shocks of interest rate and lagged exchange rates only up to one and three months, respectively, showing evidence of interest rate parity.

As a robustness check, when the sample period is split into two, the impulse response functions in Fig. 2 and Fig. 3 are obtained. While Fig. 2 shows the period of implicit inflation targeting regime over the period 20022005, Fig.3 shows the period of explicit inflation targeting regime over the period 2006-2009. As is evident, when the effects of shocks on short-term interest rates are compared, the monetary policy authorities have reacted to the volatility arising from exchange rates during the implicit inflation targeting regime, while they have reacted to the volatility arising from inflation rates during the explicit inflation targeting regime. An explanation for this type of a monetary policy can be obtained by comparing the effects of shocks on inflation rates during the two periods: the inflation rates have significantly been affected through exchange rate shocks during the implicit inflation target regime and through inflation inertia during the explicit inflation targeting regime. During the same period, when the effects of shocks on output are compared, the only new observation is the negative and significant effect of inflation shocks on output during the implicit inflation targeting regime. When it comes to credit card usage, the only new observation is the negative and significant effect of exchange rate shocks during the explicit inflation targeting regime, suggesting an increasing effect of international shocks on consumption behavior, mostly due to the global financial crisis that has started in 2007.

\subsection{Forecast Error Variance Decompositions}

The variance decomposition of forecasted variables for the period over 2002-2009 are depicted in Table 1 for different horizon periods. As is evident, the biggest and significant contribution for the forecasted variance of each variable is due to its lagged values suggesting the presence of a stable economy during the inflation targeting period; hence, we will focus on the contribution of other explanatory variables in the variance decomposition to determine possible causes of volatilities. The forecasted output variance mostly comes from credit cards followed by interest rates and exchange rates, while the forecasted variance of credit card usage is mostly explained through output followed by inflation, interest rates, and exchange rates. This shows the 
bilateral connection between the credit market and the real side of the economy. Similar to the results of impulse response functions, the forecasted variance of short-term interest rates are mostly determined by inflation and exchange rates, supporting the idea of a Taylor rule as a useful tool explaining the monetary policy conducted in Turkey during the inflation targeting regime. The forecasted inflation variance is mostly due to output and exchange rates followed by interest rates and credit cards showing the roles of demand-side effects and international shocks on the price level. Finally, the forecasted exchange rate variance is mostly determined by interest rates followed by inflation, output, and credit cards, supporting the interest rate parity.

As a robustness test, when the sample period is split into two, the variance decompositions in Table 2 and Table 3 are obtained. While Table 2 shows the period of implicit inflation targeting regime over the period 2002-2005, Table 3 shows the period of explicit inflation targeting regime over the period 2006-2009. As is evident, the standard errors of all variables have decreased during the explicit inflation targeting regime except for the inflation. When two periods are compared in terms of the variance decompositions of output, the percentage contributions of explanatory variables (other than lagged output) are much higher during the implicit inflation targeting period suggesting that output has been more stable during the explicit inflation targeting regime. Although credit card usage has mostly been affected through output during both periods, the contribution of exchange rates on the forecasted variance of credit card usage has increased during the explicit inflation targeting regime, showing evidence of increasing international shocks due to global financial crisis that has started in 2007. The variance decomposition of forecasted short-term interest rates suggests that the real side of the economy, the credit market, and international shocks were more important for the implicit inflation targeting regime, mostly due to the recovering economy after the financial crisis of 2001. Another striking evidence is the increasing contribution of exchange rates to the forecasted variance of inflation, showing the effects of the global crisis that has started in 2007. Finally, there are increasing effects of credit card usage on the forecasted variance of exchange rates, suggesting a role for the national credit market having implications on international transactions.

Nevertheless, more important policy implications are on the real side of the economy: according to Table 2 and Table 3, during the implicit (respectively, explicit) inflation-targeting period, the movements in output are determined at around 11\% (respectively, 5\%) through credit card usage, around 8\% (respectively, 3\%) by the short-term interest rates, another $8 \%$ (respectively, $0.5 \%$ ) by inflation, and $13 \%$ (respectively, $1 \%$ ) by exchange rates. This result has an important policy implication: both the credit view (through credit cards) and the monetary view (through short-term interest rates) seem to be more important during high inflationary episodes for the real side of the economy. When one compares the credit view with the money view, the former seems to be more effective on the real economy during both implicit and explicit inflation-targeting periods (i.e., this last 
result is independent of the level of inflation). From a policy maker's point of view, this result justifies the motivation of the paper that there is an increasing necessity for considering the credit channel of monetary policy transmission through credit cards.

As an additional robustness test, forecast error variance decompositions are depicted for three-year windows in Fig. 4. While the left panel of the figure depicts the variance decomposition in absolute terms, the right panel depicts the variance decomposition in percentage terms. Although the horizon length has been set equal to 6 , the results are not critically depend on this selection (see Tables 1-3 for variance decomposition calculated for different horizon lengths). As is evident, the absolute variance of output has fallen through time, especially starting from the window of 2006-2009; in percentage terms, the variance of output has also become self explanatory through time, suggesting a more stable real side of the economy. The forecasted variance of credit card usage has also decreased through time; it has been affected more by inflation rate during the implicit inflation targeting period while more by exchange rates during the explicit inflation targeting period. One interesting result is related to the forecasted variance decomposition of interest rates which suggests that monetary policy has started focusing more on output volatility and interest-rate smoothing (and less on exchange rate volatility) during the recent global financial crisis that has started in 2007. The forecasted variance of inflation has increased through time and has been mostly affected by exchange rate movements and inflation inertia during the recent global financial crisis. Credit cards usage also has an increasing effect on the inflation rate through time. Finally, the exchange rates do not seem to follow a stable path through time, suggesting unstable international shocks at all times.

\section{Conclusions}

This paper has investigated the credit channel of monetary transmission mechanism through credit card usage in a small open economy, Turkey, which has adopted an implicit inflation targeting regime in 2002 and shifted to explicit inflation targeting regime in 2006. It has been shown that credit cards usage has an increasing effect on inflation rates through time; this suggests that there will be a necessity of a monetary policy that will focus more on credit cards market in the future. The comparison of implicit and explicit inflation targeting regimes shows that the output has become more stable, while inflation rate has become less stable and started being affected more by domestic and foreign shocks during the latter. Since the explicit inflation targeting regime also includes the recent global financial crisis that has started in 2007, these results suggests that the Turkish economy has

been mostly exposed to nominal rather than real changes during the crisis period. Although this is an indicator of a successfully conducted policy, it raises precautionary concerns for the future as such nominal changes in the current economy may start leading to negative real effects after the crisis period will be over and the global economy will recover. The results of this paper also have an important policy implication: both the credit view 
(through credit cards) and the monetary view (through short-term interest rates) seem to be more important during high inflationary episodes for the real side of the economy. When one compares the credit view with the money view, the former seems to be more effective on the real economy during both implicit and explicit inflation-targeting periods (i.e., this last result is independent of the level of inflation). From a policy maker's

point of view, this suggests that there is an increasing necessity for considering the credit channel of monetary policy transmission through credit cards.

Nevertheless, the results of this paper are not without caveats: (i) this paper focuses on the credit channel through credit cards of which movements may not reflect the developments in the overall credit market; (ii) the empirical evidence is from a small-open economy, hence the results may be reflecting some country specifics; (iii) the sample period is restricted to (either implicit or explicit) inflation-targeting period due to the lack of data; comparing the inflation-targeting period with pre-inflation-targeting period might provide more interesting results for the success of the inflation-targeting regime and its relation with the credit channel; (iv) although the sample period covers most of the recent financial crisis that has started through the end of 2007, the post-crisis period (and, thus, future international shocks through the global economy) is not certain yet; more data are necessary from the future. Focusing on these details is out of the scope of this paper; nevertheless, such extensions, especially analyzing other countries if high-quality monthly data as in this paper will be available, are possible topics of future research.

\section{References:}

- Bernanke, B., (1993) “Credit in the Macroeconomy”, Quarterly Review, Federal Reserve Bank of New York, Spring, 50-70.

- Berument, H., (2007), “Measuring Monetary Policy for a Small Open Economy: Turkey”, Journal of Macroeconomics, 29: 411-430.

- Berument, H. and Pasaogullari, M., (2003), "Effects of the Real Exchange Rate on Output and Inflation: Evidence from Turkey”, The Developing Economies, XLI-4, 401-435.

- Brady, R. Ryan, “Consumer Credit, Liquidity and the Transmission Mechanism of Monetary Policy” Economic Inquiry, Forthcoming.

- Civcir, I. and Akcaglayan, A., (2010), "Inflation Targeting and the Exchange Rate: Does it Matter in Turkey”, Journal of Policy Modeling, 32: 339-354.

- Diboglu, S. and Kibritcioglu, A. (2004), "Inflation, Output Growth, and Stabilization in Turkey, 19802002”, Journal of Economics and Business, 56: 43-61. 
- Gertler, Mark, and Simon Gilchrest, (1993), "The Role of Credit Market Imperfections in the Monetary Transmission Mechanism: Arguments and Evidence,” Scandinavian Journal of Economics, 95(1), 43-64.

- Gertler, Mark, and Simon Gilchrest, (1994), "Monetary Policy, Business Cycles, and the Behavior of Small Manufacturing Firms,” Quarterly Journal of Economics, 109(2), 309-340.

- Kashyap, Anil, K., and Jeremy C. Stein, "The Impact of Monetary Policy on Bank Balance Sheets," Carnegie-Rochester Conference Series on Public Policy, 42 (1995),, 151-195.

- Kashyap, Anil, K, and Jeremy C. Stein, "What do a Million Observations on Banks Say About the Transmission of Monetary Policy,” The American Economic Review, 90, 3 (June 2000), 407-428.

- King, Stephen, "Monetary Transmission Through Bank Loans or Bank Liabilities”, Journal of Money, Credit and Banking, 1986, 290-303.

- Kishan, R.P., and T.P. Opelia (2000), “Bank Size, Bank Capital, and the Bank Lending Channel,” Journal of Money, Credit and Banking, 32(1), 121-141.

- Leigh, D. and Rossi, M., (2002), "Exchange Rate Pass-Through in Turkey”, IMF Working Paper $\mathrm{WP} / 02 / 204$.

- Ramey, Valerie, "How Important is the Credit Channel in the Transmission of Monetary Policy", CarnegieRochester Conference Series on Public Policy, 1993.

- Romer, Christina, and David Romer, "New Evidence on the Monetary Transmission Mechanism”, Brooking Papers on Economic Activity, 1990, 149-98.

- Us, V. (2004), "Inflation Dynamics and Monetary Policy Strategy: Some Prospects for the Turkish Economy”, Journal of Policy Modeling, 26: 1003-1013.

- Yazgan, M.E. and Yilmazkuday, H., "Effects of Credit and Debit Cards on the Currency Demand”, Applied Economics, 2009, 41(17): 2115-2123. 
Table 1. Variance Decomposition of Forecasted Variables between 2002:M2 - 2009:M12

\begin{tabular}{|c|c|c|c|c|c|c|}
\hline Period & Standard Error & Output & Credit & Interest & Inflation & Exchange \\
\hline \multicolumn{7}{|c|}{ Variance Decomposition of Output } \\
\hline 1 & 40.11 & $100(0)$ & $0(0)$ & $0(0)$ & $0(0)$ & $0(0)$ \\
\hline 3 & 50.37 & $88(7)$ & $4(2)$ & $4(2)$ & $1(1)$ & $3(2)$ \\
\hline 6 & 51.43 & $85(8)$ & $7(3)$ & $4(2)$ & 1(1) & $3(2)$ \\
\hline 9 & 51.48 & $85(8)$ & $7(3)$ & $4(2)$ & 1(1) & $3(2)$ \\
\hline 12 & 51.49 & $85(8)$ & $7(3)$ & $4(2)$ & $1(1)$ & $3(2)$ \\
\hline
\end{tabular}

\begin{tabular}{|c|c|c|c|c|c|c|}
\hline \multicolumn{7}{|c|}{ Variance Decomposition of Credit Card Usage } \\
\hline 1 & 26.93 & $9(5)$ & $91(6)$ & $0(0)$ & $0(0)$ & $0(0)$ \\
\hline 3 & 30.72 & $12(6)$ & $79(8)$ & $3(2)$ & $3(2)$ & $3(3)$ \\
\hline 6 & 31.55 & $14(6)$ & $75(9)$ & $4(2)$ & $4(3)$ & $3(3)$ \\
\hline 9 & 31.60 & 14(6) & $75(9)$ & $4(2)$ & $4(3)$ & $3(3)$ \\
\hline 12 & 31.60 & $14(6)$ & $75(9)$ & $4(2)$ & $4(3)$ & $3(3)$ \\
\hline \multicolumn{7}{|c|}{ Variance Decomposition of Interest Rates } \\
\hline 1 & 0.94 & $5(3)$ & $0(2)$ & $95(4)$ & $0(0)$ & $0(0)$ \\
\hline 3 & 1.11 & $5(3)$ & $3(4)$ & $80(9)$ & $6(4)$ & $6(6)$ \\
\hline 6 & 1.14 & $5(3)$ & $3(4)$ & $78(9)$ & $7(4)$ & $7(7)$ \\
\hline 9 & 1.14 & $5(3)$ & $3(4)$ & $78(9)$ & $7(4)$ & $7(7)$ \\
\hline 12 & 1.14 & $5(3)$ & $3(4)$ & $78(9)$ & $7(4)$ & $7(7)$ \\
\hline \multicolumn{7}{|c|}{ Variance Decomposition of Inflation Rates } \\
\hline 1 & 5.41 & $5(4)$ & $1(0)$ & $4(2)$ & $90(6)$ & $0(0)$ \\
\hline 3 & 6.88 & $5(4)$ & $3(1)$ & $4(2)$ & $82(9)$ & $6(3)$ \\
\hline 6 & 7.00 & $7(5)$ & $3(1)$ & $4(2)$ & $80(10)$ & $6(3)$ \\
\hline 9 & 7.01 & $7(5)$ & $3(1)$ & $4(2)$ & $80(10)$ & $6(3)$ \\
\hline 12 & 7.01 & $7(5)$ & $3(1)$ & $4(2)$ & $80(10)$ & $6(3)$ \\
\hline \multicolumn{7}{|c|}{ Variance Decomposition of Exchange Rates } \\
\hline 1 & 40.91 & $0(1)$ & $0(1)$ & $9(6)$ & $5(4)$ & $86(7)$ \\
\hline 3 & 45.93 & $2(2)$ & $1(2)$ & $11(6)$ & $6(4)$ & $80(7)$ \\
\hline 6 & 47.70 & $2(2)$ & 2(3) & $13(6)$ & $7(4)$ & $76(8)$ \\
\hline 9 & 47.84 & $2(2)$ & 2(3) & $13(6)$ & $7(4)$ & $76(8)$ \\
\hline 12 & 47.86 & $2(2)$ & 2(3) & $13(6)$ & $7(4)$ & $76(8)$ \\
\hline
\end{tabular}


Table 2. Variance Decomposition of Forecasted Variables between 2002:M2 - 2005:M12

\begin{tabular}{ccccccc}
\hline Period & $\begin{array}{c}\text { Standard } \\
\text { Error }\end{array}$ & Output & Credit & Interest & Inflation & Exchange \\
\hline \multicolumn{7}{c}{ Variance Decomposition of Output } \\
\hline \multicolumn{7}{c}{} \\
1 & 33.94 & $100(0)$ & $0(0)$ & $0(0)$ & $0(0)$ & $0(0)$ \\
3 & 51.33 & $65(13)$ & $7(3)$ & $7(4)$ & $8(5)$ & $13(7)$ \\
6 & 53.68 & $60(13)$ & $11(5)$ & $8(4)$ & $8(5)$ & $13(7)$ \\
9 & 53.70 & $60(14)$ & $11(5)$ & $8(4)$ & $8(5)$ & $13(7)$ \\
12 & 53.70 & $60(14)$ & $11(5)$ & $8(4)$ & $8(5)$ & $13(7)$
\end{tabular}

\begin{tabular}{|c|c|c|c|c|c|c|}
\hline \multicolumn{7}{|c|}{ Variance Decomposition of Credit Card Usage } \\
\hline 1 & 29.38 & $8(9)$ & $92(9)$ & $0(0)$ & $0(0)$ & $0(0)$ \\
\hline 3 & 32.59 & $15(9)$ & $78(11)$ & $3(3)$ & $3(3)$ & $1(2)$ \\
\hline 6 & 34.65 & 18(9) & $70(13)$ & $3(3)$ & $5(3)$ & $4(2)$ \\
\hline 9 & 34.94 & $18(9)$ & $70(13)$ & $4(4)$ & $4(3)$ & $4(2)$ \\
\hline 12 & 34.95 & $18(9)$ & $70(13)$ & $4(4)$ & $4(3)$ & $4(2)$ \\
\hline \multicolumn{7}{|c|}{ Variance Decomposition of Interest Rates } \\
\hline 1 & 0.96 & $5(5)$ & $2(2)$ & $93(8)$ & $0(0)$ & $0(0)$ \\
\hline 3 & 1.25 & $9(7)$ & $11(9)$ & 61(11) & $6(3)$ & $13(6)$ \\
\hline 6 & 1.30 & $9(7)$ & $11(9)$ & $60(11)$ & $6(3)$ & $14(7)$ \\
\hline 9 & 1.31 & $9(7)$ & 11(9) & $60(11)$ & $6(3)$ & $14(7)$ \\
\hline 12 & 1.31 & $9(7)$ & 11(9) & $60(11)$ & $6(3)$ & $14(7)$ \\
\hline \multicolumn{7}{|c|}{ Variance Decomposition of Inflation Rates } \\
\hline 1 & 4.16 & $5(4)$ & $1(1)$ & $3(2)$ & $91(10)$ & $0(0)$ \\
\hline 3 & 5.26 & $11(6)$ & 1(1) & $5(3)$ & $74(11)$ & $9(4)$ \\
\hline 6 & 5.62 & $12(7)$ & $4(2)$ & $8(4)$ & $65(12)$ & $11(5)$ \\
\hline 9 & 5.64 & $12(7)$ & $4(2)$ & $8(4)$ & $65(12)$ & $11(5)$ \\
\hline 12 & 5.64 & $12(7)$ & $4(2)$ & $8(4)$ & $65(12)$ & $11(5)$ \\
\hline \multicolumn{7}{|c|}{ Variance Decomposition of Exchange Rates } \\
\hline 1 & 36.71 & $0(1)$ & $3(2)$ & $7(4)$ & $3(3)$ & $87(8)$ \\
\hline 3 & 44.22 & $6(5)$ & $8(5)$ & $17(8)$ & $4(4)$ & $68(9)$ \\
\hline 6 & 47.17 & $6(5)$ & $8(5)$ & 17(8) & $5(5)$ & $64(9)$ \\
\hline 9 & 47.44 & $6(5)$ & $8(5)$ & 17(8) & $6(5)$ & $63(10)$ \\
\hline 12 & 47.50 & $6(5)$ & $8(5)$ & $17(8)$ & $6(5)$ & $63(10)$ \\
\hline
\end{tabular}

Notes: Standard errors calculated by Monte Carlo simulations with 100 repetitions are in parenthesis. 
Table 3. Variance Decomposition of Forecasted Variables between 2006:M1 - 2009:M12

\begin{tabular}{ccccccc}
\hline Period & $\begin{array}{c}\text { Standard } \\
\text { Error }\end{array}$ & Output & Credit & Interest & Inflation & Exchange \\
\hline \multicolumn{7}{c}{ Variance Decomposition of Output } \\
\hline \multicolumn{7}{c}{} \\
1 & 41.84 & $100(0)$ & $0(0)$ & $0(0)$ & $0(0)$ & $0(0)$ \\
3 & 48.36 & $95(6)$ & $1(2)$ & $3(2)$ & $0(1)$ & $1(3)$ \\
6 & 49.53 & $91(12)$ & $5(3)$ & $3(2)$ & $0(2)$ & $1(3)$ \\
9 & 49.61 & $91(12)$ & $5(3)$ & $3(2)$ & $0(2)$ & $1(4)$ \\
12 & 49.62 & $91(13)$ & $5(3)$ & $3(2)$ & $0(2)$ & $1(4)$
\end{tabular}

\begin{tabular}{|c|c|c|c|c|c|c|}
\hline \multicolumn{7}{|c|}{ Variance Decomposition of Credit Card Usage } \\
\hline 1 & 21.19 & $18(7)$ & $82(10)$ & $0(1)$ & $0(0)$ & $0(0)$ \\
\hline 3 & 27.17 & $16(6)$ & 73(11) & 2(1) & $1(1)$ & $8(3)$ \\
\hline 6 & 27.59 & $17(8)$ & $72(12)$ & 2(1) & 1(1) & $8(3)$ \\
\hline 9 & 27.63 & $17(8)$ & $72(12)$ & 2(1) & $1(1)$ & $8(3)$ \\
\hline 12 & 27.64 & $17(8)$ & $72(12)$ & 2(1) & $1(1)$ & $8(3)$ \\
\hline \multicolumn{7}{|c|}{ Variance Decomposition of Interest Rates } \\
\hline 1 & 0.72 & $6(4)$ & $2(2)$ & $92(8)$ & $0(0)$ & $0(0)$ \\
\hline 3 & 0.83 & $4(3)$ & $2(2)$ & $85(10)$ & $6(2)$ & $3(4)$ \\
\hline 6 & 0.89 & $5(3)$ & $3(4)$ & $77(12)$ & $7(3)$ & $8(5)$ \\
\hline 9 & 0.90 & $5(3)$ & $3(4)$ & $75(13)$ & $7(4)$ & $10(6)$ \\
\hline 12 & 0.91 & $5(3)$ & $3(4)$ & $75(13)$ & $7(5)$ & $10(6)$ \\
\hline \multicolumn{7}{|c|}{ Variance Decomposition of Inflation Rates } \\
\hline 1 & 4.32 & $6(4)$ & $4(2)$ & $1(0)$ & $89(9)$ & $0(0)$ \\
\hline 3 & 7.42 & $3(2)$ & $9(3)$ & $10(4)$ & $52(10)$ & $26(10)$ \\
\hline 6 & 7.89 & $5(3)$ & $11(4)$ & $11(4)$ & $50(11)$ & $24(9)$ \\
\hline 9 & 8.01 & $5(3)$ & 10(3) & $11(4)$ & $49(11)$ & 25(9) \\
\hline 12 & 8.04 & $5(3)$ & $10(3)$ & $11(4)$ & $49(11)$ & $25(9)$ \\
\hline \multicolumn{7}{|c|}{ Variance Decomposition of Exchange Rates } \\
\hline 1 & 37.63 & $0(3)$ & $4(3)$ & $5(4)$ & $13(7)$ & $78(11)$ \\
\hline 3 & 43.99 & $0(4)$ & $5(4)$ & $4(3)$ & $11(5)$ & $80(10)$ \\
\hline 6 & 46.39 & $0(4)$ & $6(5)$ & $7(8)$ & $11(5)$ & $76(10)$ \\
\hline 9 & 46.72 & $1(5)$ & $6(5)$ & $7(8)$ & 11(5) & $75(10)$ \\
\hline 12 & 46.76 & $1(5)$ & $6(6)$ & $7(8)$ & 11(6) & $75(10)$ \\
\hline
\end{tabular}

Notes: Standard errors calculated by Monte Carlo simulations with 100 repetitions are in parenthesis. 
Fig. 1 - Impulse Response Functions between 2002:M2 - 2009:M12

Response to Cholesky One S.D. Innov ations \pm 2 S.E.

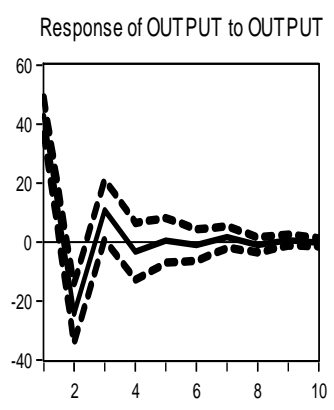

Response of CREDIT to OUTPUT

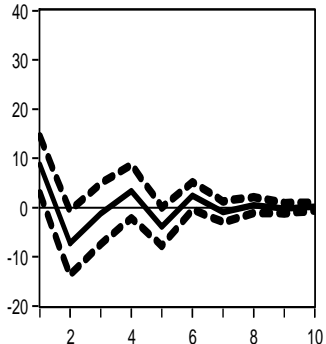

Response of INTEREST to OUTPUT

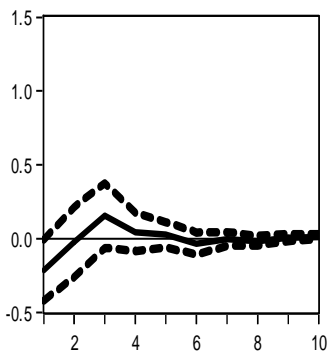

Response of INFLATION to OUTPUT

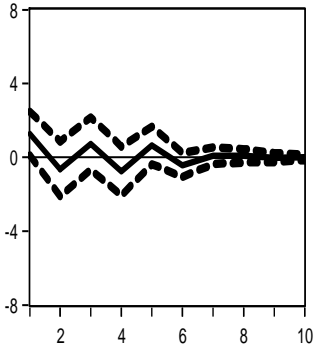

Response of EXCHANGE to OUTPUT

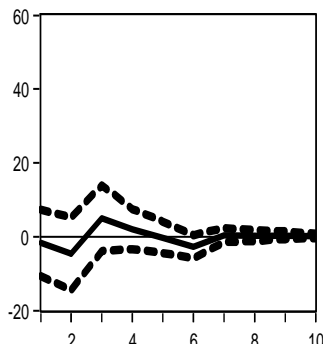

Response of OUTPUT to CREDIT

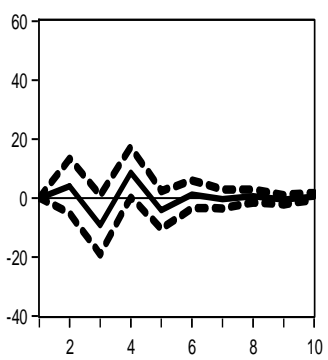

Response of CREDIT to CREDIT

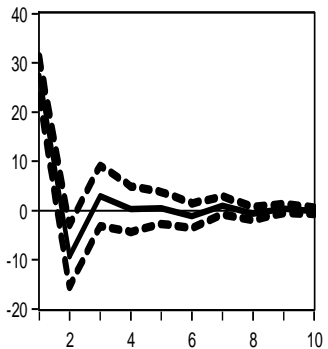

Response of INTEREST to CREDIT

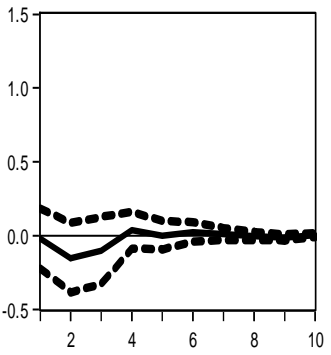

Response of INFLATION to CREDIT

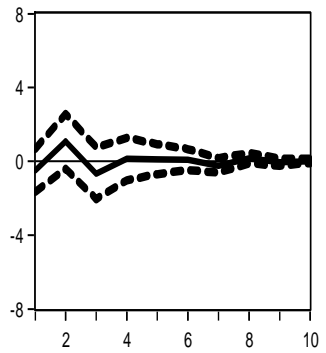

Response of EXCHANGE to CREDIT

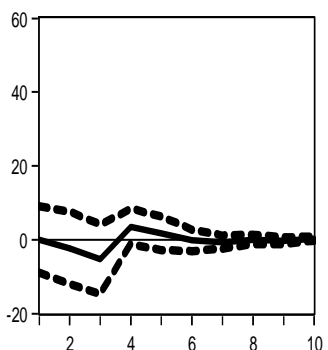

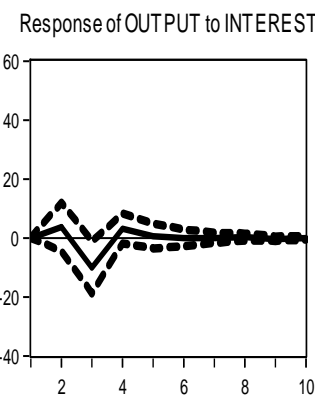

Response of CREDIT to INTEREST

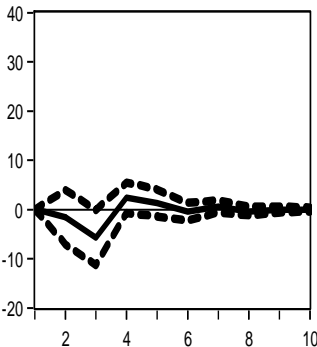

Response of INTEREST to INTEREST

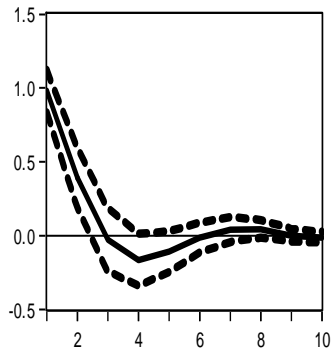

Response of INFLATION to INTEREST

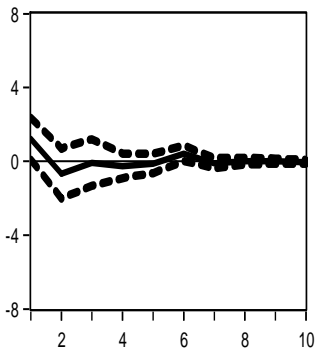

Response of EXCHANGE to INTEREST

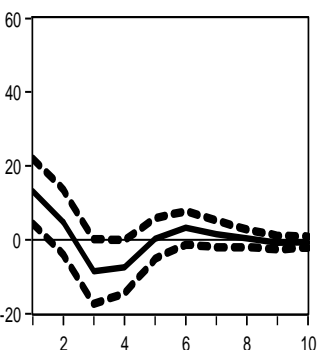

Response of OUTPUT to INFLATION

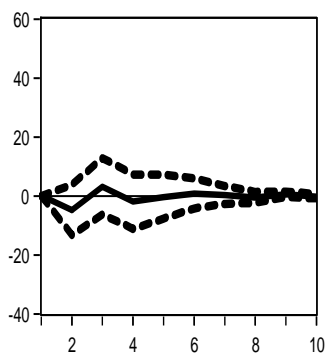

Response of CREDIT to INFLATION

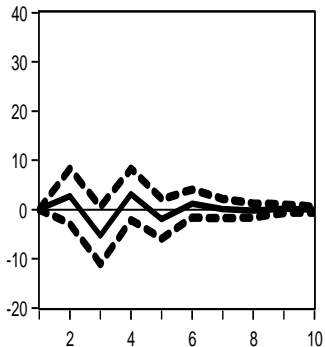

Response of INTEREST to INFLATION

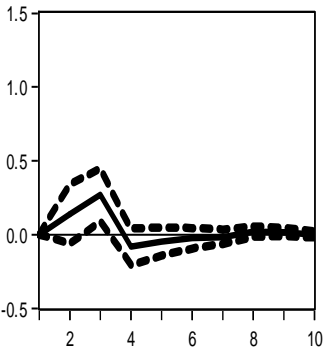

Response of INFLATION to INFLATION

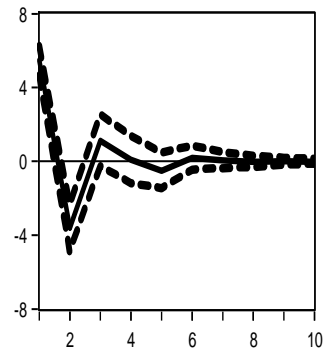

Response of EXCHANGE to INFLATION

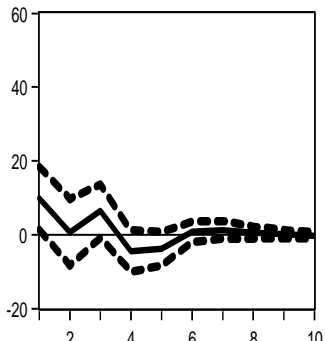

Response of OUTPUT to EXCHANGE

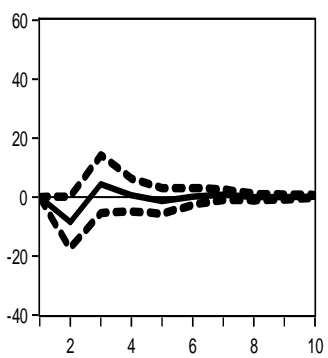

Response of CREDIT to EXCHANGE

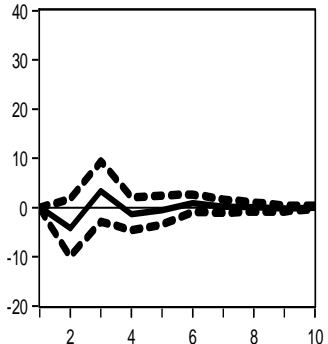

Response of INTEREST to EXCHANGE

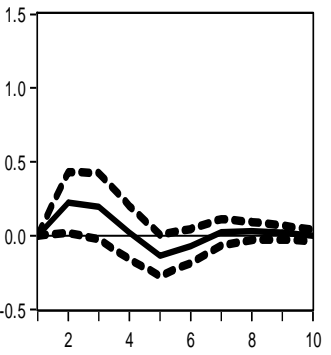

Response of INFLATION to EXCHANGE

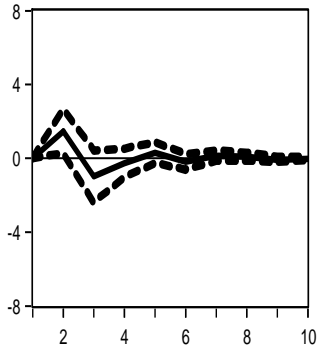

Response of EXCHANGE to EXCHANGE

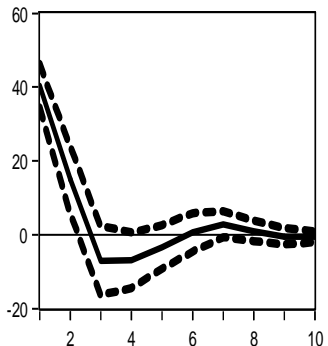


Fig. 2 - Impulse Response Functions between 2002:M2 - 2005:M12

Response to Cholesky One S.D. Innovations \pm 2 S.E.

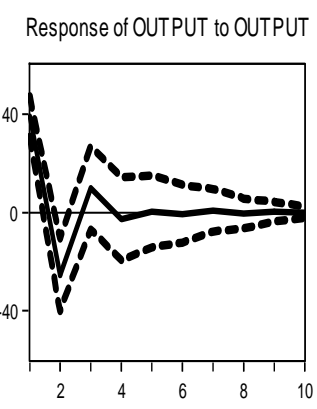

Response of CREDIT to OUTPUT

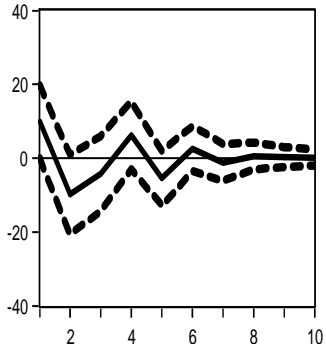

Response of INTEREST to OUTPUT

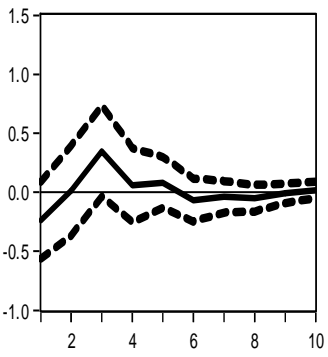

Response of INFLATION to OUTPUT

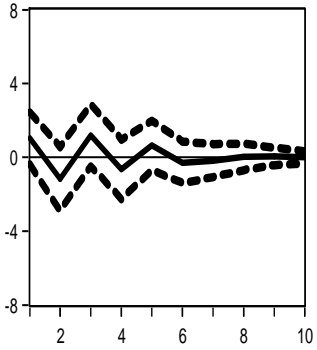

Response of EXCHANGE to OUTPUT

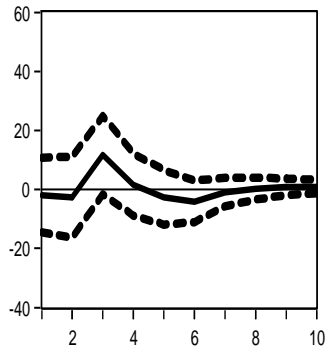

Response of OUTPUT to CREDIT

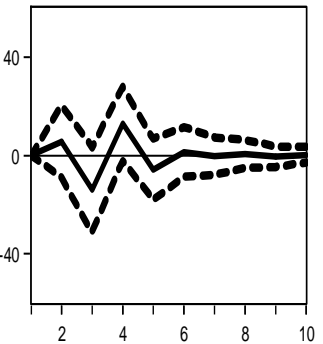

Response of CREDIT to CREDIT

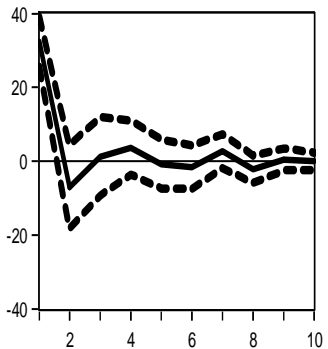

Response of INTEREST to CREDIT

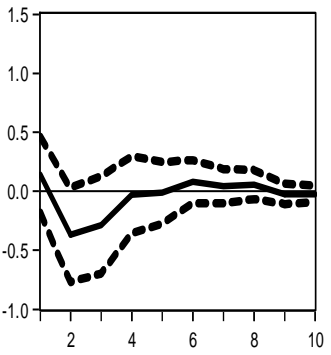

Response of INFLATION to CREDIT

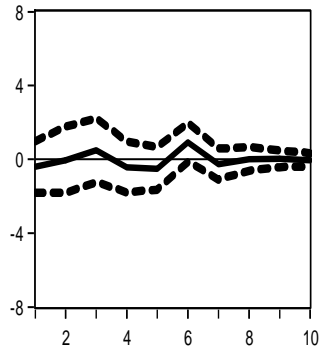

Response of EXCHANGE to CREDIT

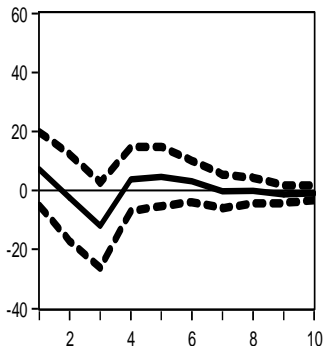

Response of OUTPUT to INTEREST

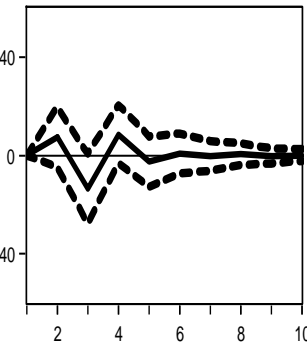

Response of CREDIT to INTEREST

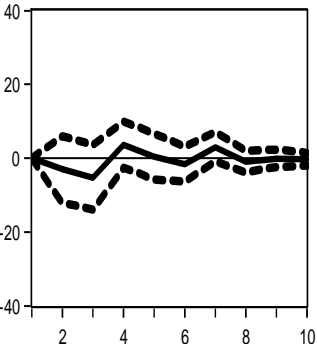

Response of INTEREST to INTEREST

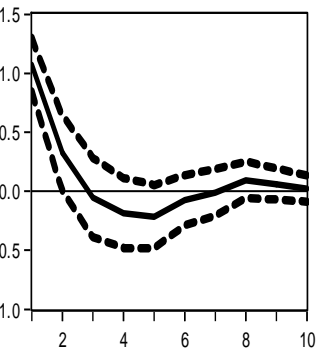

Response of INFLATION to INTEREST

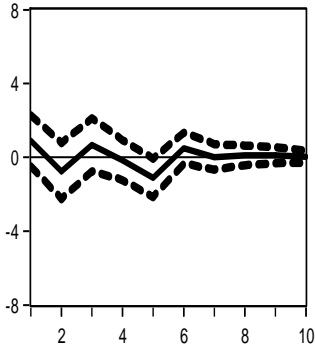

Response of EXCHANGE to INTEREST

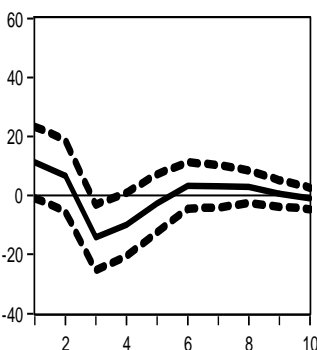

Response of OUTPUT to INFLATION

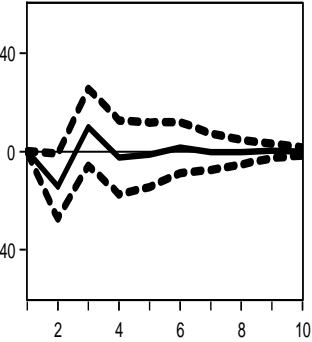

Response of CREDIT to INFLATION

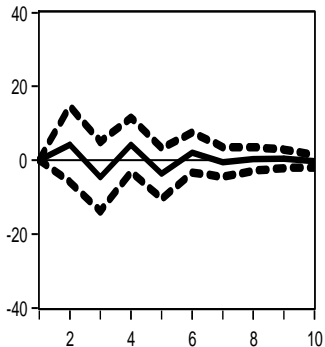

Response of INTEREST to INFLATION

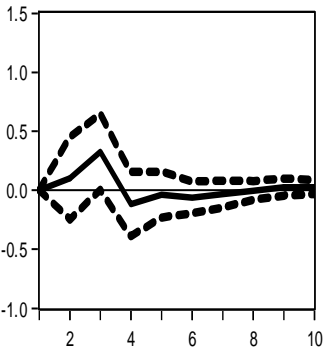

Response of INFLATION to INFLATION

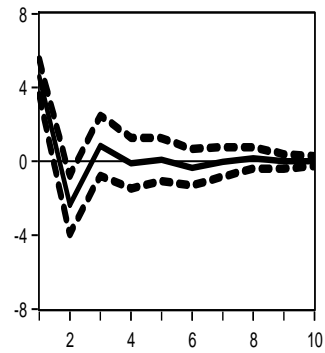

Response of EXCHANGE to INFLATION

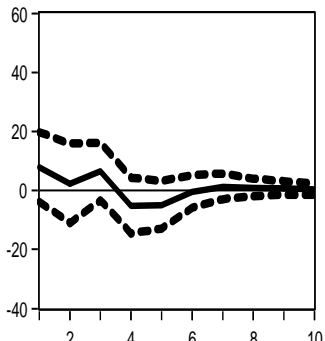

Response of OUTPUT to EXCHANGE

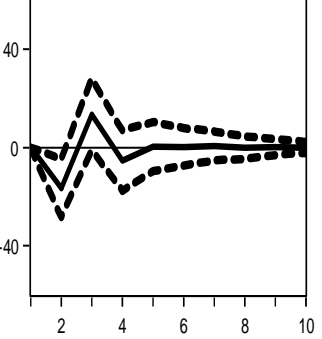

Response of CREDIT to EXCHANGE

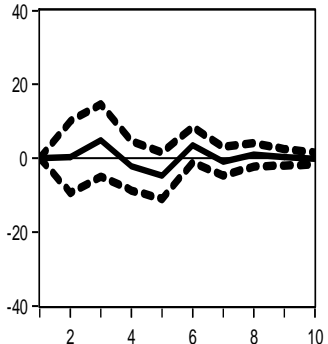

Response of INTEREST to EXCHANGE

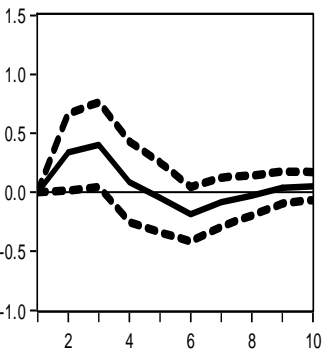

Response of INFLATION to EXCHANGE

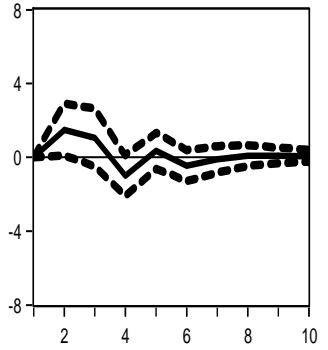

Response of EXCHANGE to EXCHANGE

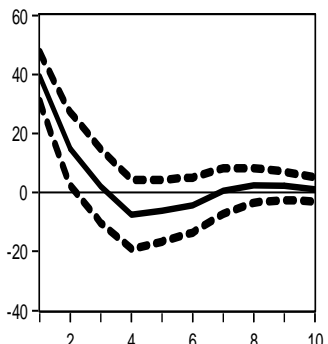


Fig. 3 - Impulse Response Functions between 2006:M1 - 2009:M12

Response to Cholesky One S.D. Innov ations \pm 2 S.E.

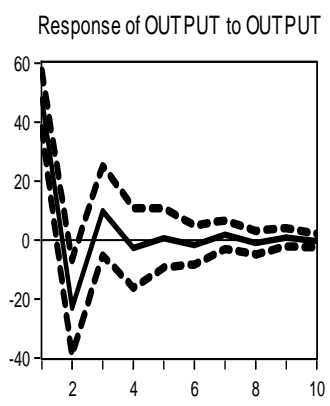

Response of CREDIT to OUTPUT

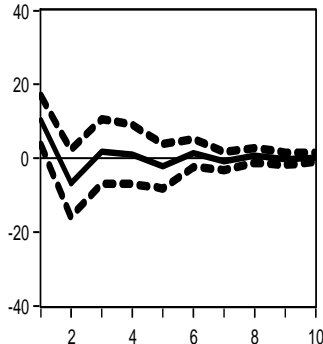

Response of INTEREST to OUTPUT

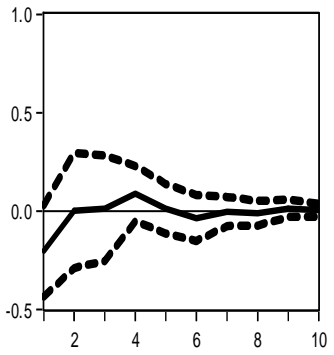

Response of INFLATION to OUTPUT

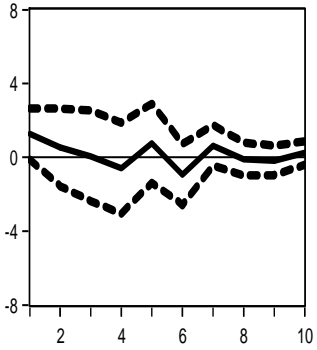

Response of EXCHANGE to OUTPUT

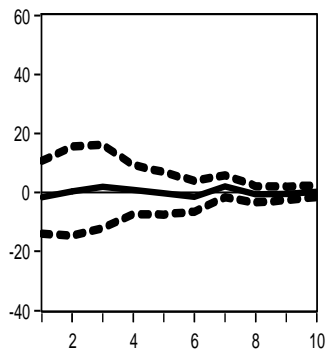

Response of OUTPUT to CREDIT

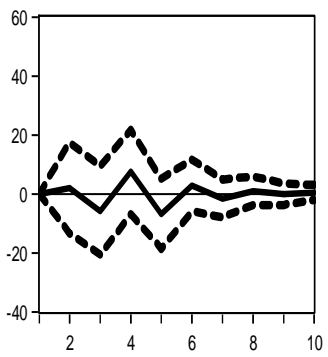

Response of CREDIT to CREDIT

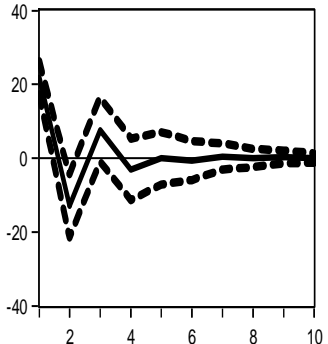

Response of INTEREST to CREDIT

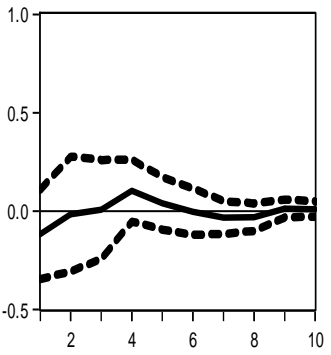

Response of INFLATION to CREDIT

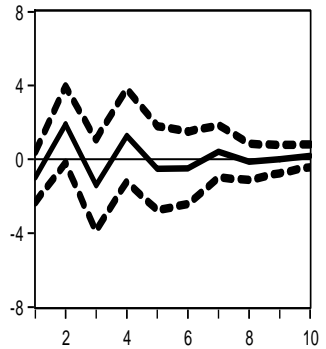

Response of EXCHANGE to CREDIT

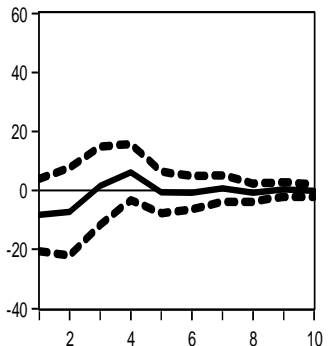

Response of OUTPUT to INTEREST

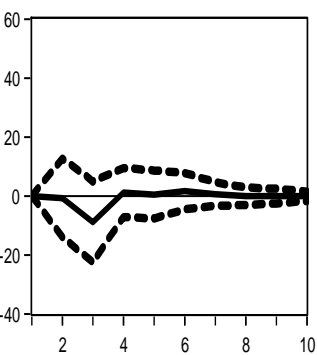

Response of CREDIT to INTEREST

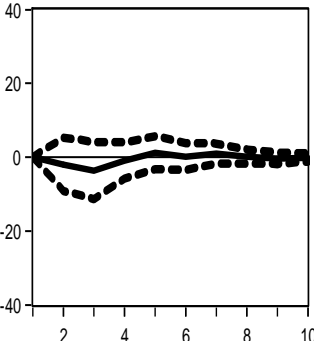

Response of INTEREST to INTEREST

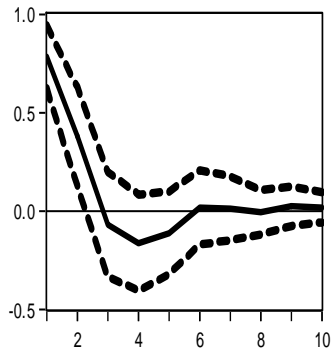

Response of INFLATION to INTEREST

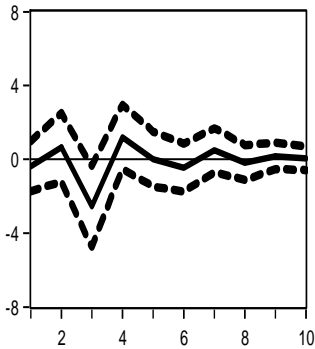

Response of EXCHANGE to INTEREST

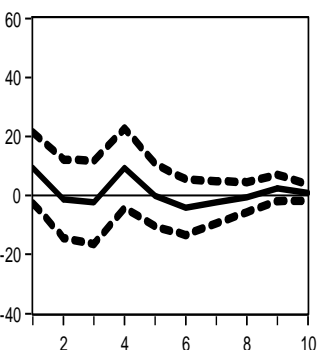

Response of OUTPUT to INFLATION

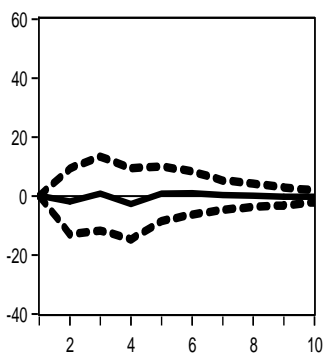

Response of CREDIT to INFLATION

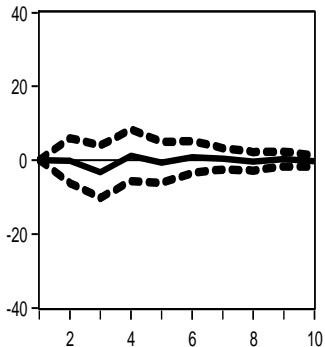

Response of INTEREST to INFLATION

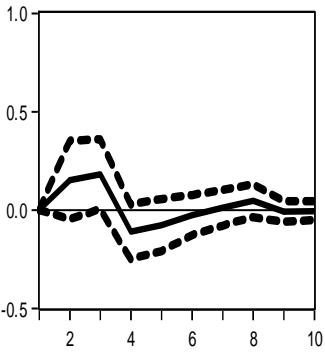

Response of INFLATION to INFLATION

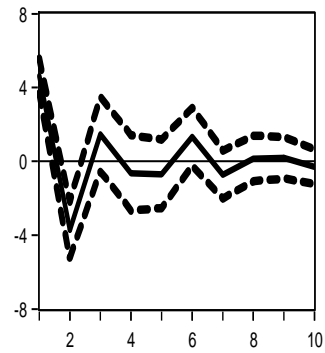

Response of EXCHANGE to INFLATION

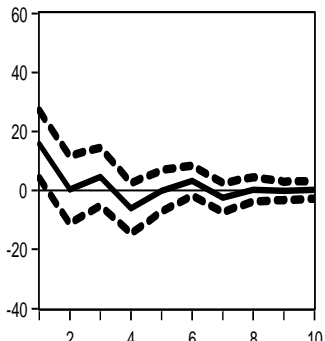

Response of OUTPUT to EXCHANGE

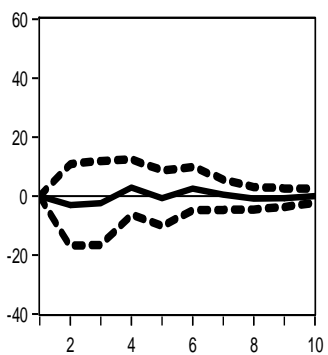

Response of CREDIT to EXCHANGE

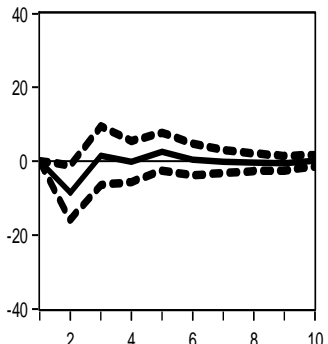

Response of INTEREST to EXCHANGE

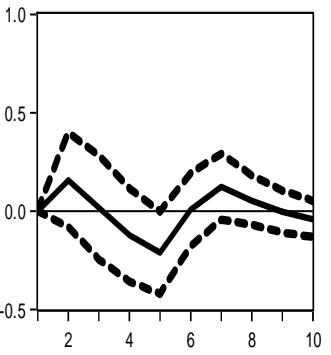

Response of INFLATION to EXCHANGE

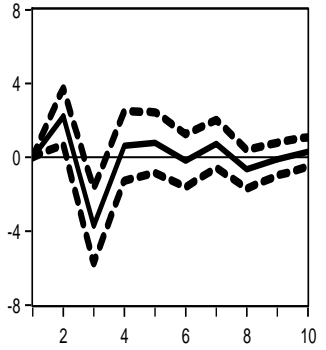

Response of EXCHANGE to EXCHANGE

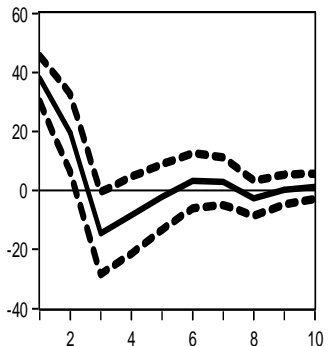


Fig. 4 - Variance Decomposition of Forecasted Variables

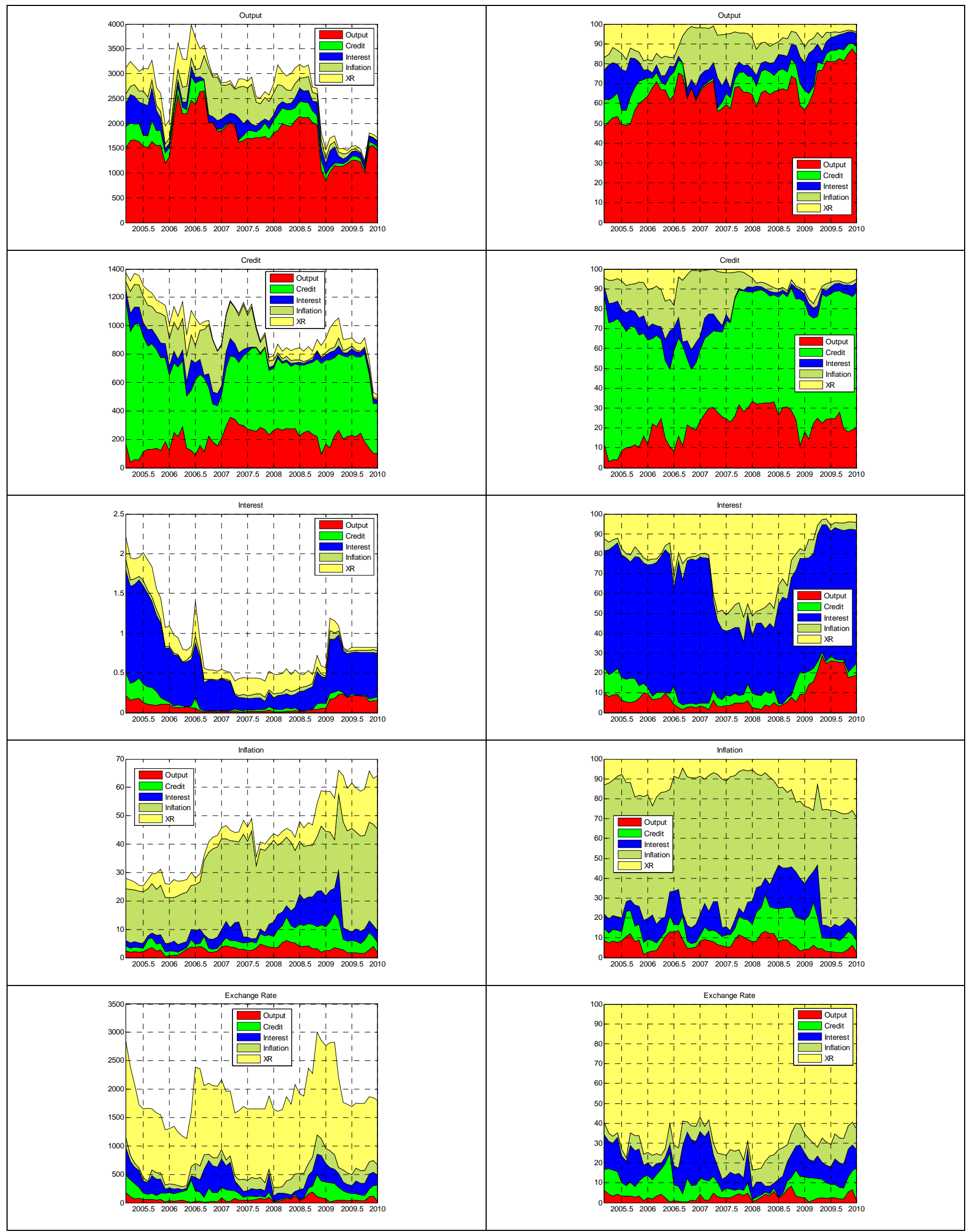

Notes: The left panel of the figure depicts the variance decomposition in absolute terms, while the right panel depicts the variance decomposition in percentage terms. The horizon length has been set equal to 6 . The $x$-axes show the end date of three-year windows and y-axes show the forecasted variances. 


\section{DATA APPENDIX}

All variables originally introduced in the text are annual percentage changes that have been seasonally adjusted and Hodrick-Prescott (HP) filtered. The monthly data covering the period over 2002-2009 have been obtained from the web page of Global Insight except for credit card usage data that have been obtained from Interbank Card Center of Turkey. Figure A.1 present the variables actually used within the VAR analysis, while Table A.1 depicts descriptive statistics (with zero means due to HP filtering), and Table A.2 is the correlation table. As is evident, the only normally distributed series is credit card usage according to Jarque-Bera normality test. Credit card usage is most correlated with output, while inflation and interest rates are most correlated with exchange rate.

Figure A.1 - Variables used in the VAR Analysis

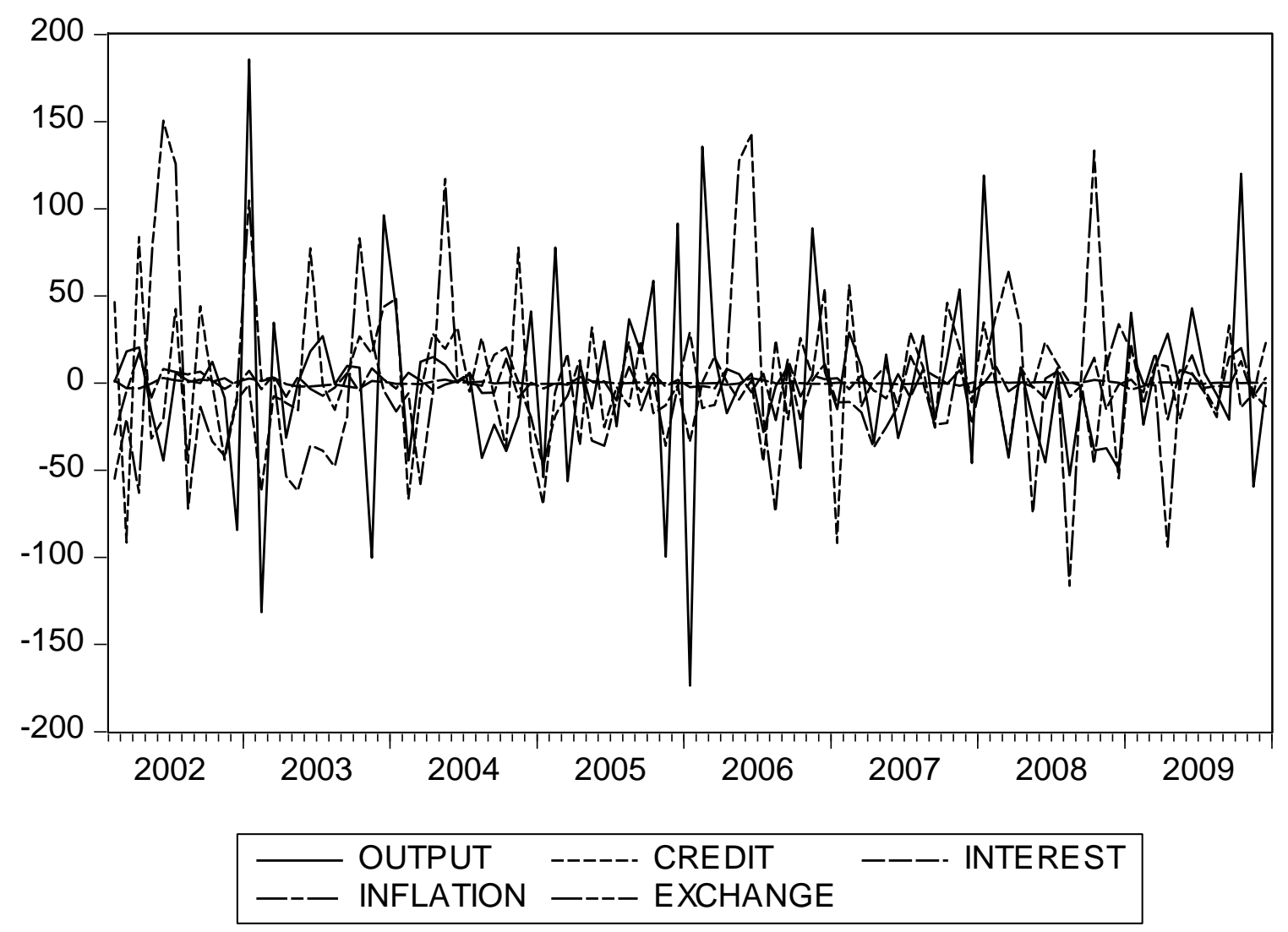


Table A.1 - Descriptive Statistics

\begin{tabular}{lccccc}
\hline & OUTPUT & CREDIT & INTEREST & INFLATION & EXCHANGE \\
\cline { 2 - 5 } Mean & 0.00 & 0.00 & 0.00 & 0.00 & 0.00 \\
Median & 0.40 & -0.97 & 0.08 & -0.23 & -4.22 \\
Maximum & 185.60 & 83.80 & 2.95 & 17.24 & 150.61 \\
Minimum & -173.50 & -91.70 & -3.91 & -29.55 & -116.35 \\
Std. Dev. & 51.82 & 33.45 & 1.22 & 7.74 & 48.38 \\
Skewness & 0.31 & -0.16 & -0.58 & -0.64 & 1.09 \\
Kurtosis & 5.62 & 3.54 & 4.94 & 4.93 & 5.09 \\
& & & & & \\
Jarque-Bera & 28.68 & 1.56 & 20.17 & 21.16 & 36.07 \\
Probability & 0.00 & 0.46 & 0.00 & 0.00 & 0.00 \\
& & & & & 0.00 \\
Sum & 0.00 & 0.00 & 0.00 & 0.00 & 219,999 \\
Sum Sq. Dev. & 252,378 & 105,179 & 139 & 5,635 & \\
Observations & & & 95 & 95 & \\
\hline
\end{tabular}

Table A.2 - Correlation Table

\begin{tabular}{cccccc}
\hline & OUTPUT & CREDIT & INTEREST & INFLATIONEXCHANGE \\
\cline { 2 - 6 } OUTPUT & 1.00 & - & - & - & - \\
CREDIT & 0.25 & 1.00 & - & - & - \\
INTEREST & -0.07 & -0.03 & 1.00 & - & - \\
INFLATION & 0.18 & -0.16 & 0.01 & 1.00 & - \\
EXCHANGE & 0.05 & -0.05 & 0.36 & 0.30 & 1.00 \\
\hline
\end{tabular}

